\title{
Analisis Bahan Pewarna Sintetis Non Pangan Rhodamin B dan Methanyl Yellow Pada Produk Saus Tomat Dan Saus Cabe Di Kota Banda Aceh
} (Non Food Synthetic Dye Chemical Analysis of Rhodamine B and Methanyl Yellow on Tomato Sauce and Chilli Sauce In Banda Aceh)

\author{
Ulul Azmi $^{1}$, Melly Novita ${ }^{1}$, Ismail Sulaiman ${ }^{{ }^{*}}$ \\ ${ }^{1}$ Program Studi Teknologi Hasil Pertanian, FakultasPertanian, UniversitasSyiah Kuala
}

\begin{abstract}
Abstrak. Penelitian ini bertujuan untuk mengidentifikasi bahan tambahan pewarna non pangan Rhodamin B dan Methanyl Yellow pada produk saus tomat dan saus cabe di kota Banda Aceh. Penelitian ini menggunakan metode penelitian survei konsumen dan analisis pewarna. Survei konsumen dilakukan dengan teknik incidental sampling yaitu penentuan responden berdasarkan kebetulan, yaitu siapa saja yang membeli produk saus dapat dijadikan sebagai responden. sedangkan analisis pewarna dilakukan secara kualitatif yaitu mengidentifikasi ada tidaknya kandungan bahan tambahan pewarna Rhodamin B dan Methanyl Yellow pada tiap sampel. Pada uji kualitatif zat pewarna Rhodamin B dan Methanyl Yellow diperoleh hasil bahwa tidak terdeteksi adanya kandungan zat pewarna Rhodamin B dan Methanyl Yellow pada keenam sampel saus tomat yang dianalisis.
\end{abstract}

Kata kunci : saus, tomat, rhodamin b, methanyl yellow.

\begin{abstract}
This study aims to identify non-food coloring additives of Rhodamin B and Methanyl Yellow in tomato sauce and chilli sauce products in the city of Banda Aceh. This research used consumer survey research methods and dye analysis. Consumer survey was done by incidental sampling technique in which the determination of respondent is decided by chance so that anyone bought sauce product can be made as respondent. While the dye analysis was conducted qualitatively, the presence of additive material of Rhodamin B and Methanyl Yellow dyes in each sample was identified. In the qualitative test of Rhodamin B and Methanyl Yellow, it was found that no detectable content of Rhodamin B and Methanyl Yellow dyes in the six samples of tomato sauce analyzed.
\end{abstract}

Keyword : sauce, tomato, rhodamin b, methanyl yellow.

\section{PENDAHULUAN}

Saus tomat dan saus cabe adalah bumbu penyedap makanan berbentuk bubur yang terbuat dari buah tomat dan cabe yang sudah masak dan ditambah dengan campuran gula, garam, cuka, rempah-rempah seperti cengkeh dan kayu manis. Selain bahan-bahan tersebut, juga ditambahkan beberapa bahan tambahan makanan seperti pewarna, pengawet, penyedap rasa, aroma, antioksidan, pengental dan pemanis. Penambahan bahan tersebut bertujuan untuk meningkatkan mutu produk saus, sehingga produk tersebut mampu bersaing di pasaran. Menurut Budianto (2008) bahan tambahan makanan adalah bahan yang ditambahkan dengan sengaja dan kemudian terdapat dalam makanan sebagai akibat dari berbagai tahap pengolahan, penyimpanan, maupun pengemasan. Tujuan penambahan bahan tambahan salah satunya untuk memperbaiki penampakan atau aroma makanan.

Dalam masyarakat seringkali terjadi penyalahgunaan zat pewarna untuk sembarang bahan pangan, misalnya zat pewarna untuk tekstil dan kulit dipakai untuk mewarnai bahan pangan. Hal ini jelas sangat berbahaya bagi kesehatan karena adanya residu logam berat pada zat pewarna tekstil. Timbulnya penyalahgunaan tersebut antara lain disebabkan oleh ketidaktahuan masyarakat mengenai zat pewarna untuk pangan, dan disamping itu harga zat pewarna untuk industri jauh lebih murah dibandingkan dengan harga zat pewarna untuk pangan.

Bahan pewarna non pangan yang sering digunakan adalah pewarna tekstil, kertas, cat seperti Rhodamin B, Methanyl Yellow, dan amaranth. Rhodamin B adalah zat warna sintetis berbentuk serbuk kristal berwarna kehijauan, berwarna merah keunguan dalam bentuk terlarut 
pada konsentrasi tinggi dan berwarna merah terang pada konsentrasi rendah. Menurut Yuliarti (2007) penggunaan Rhodamin B pada makanan dalam waktu yang lama dapat mengakibatkan gangguan fungsi hati maupun penyakit kanker. Namun demikian, bila terpapar Rodamin $B$ dalam jumlah besar maka dalam waktu singkat dapat terjadi gejala akut keracunan Rhodamin $B$.

Methanyl Yellow merupakan zat pewarna sintetis yang berbentuk serbuk atau padat berwarna kuning kecoklatan dan dilarang untuk produk makanan karena dalam bahan tersebut mengandung residu logam berat yang sangat membahayakan. Paparan kronik methanyl yellow pada manusia bersifat iritan sehingga dapat menyebabkan iritasi saluran cerna. Selain itu, methanyl yellow dapat menyebabkan mual, muntah, sakit perut, diare, demam, lemah, dan hipotensi.

Zat pewarna yang diizinkan penggunaannya dalam makanan dikenal sebagai permitted color atau certified color. Untuk penggunaan zat warna tersebut harus menjalani tes dan prosedur penggunaan yang disebut proses sertifikasi. Proses sertifikasi ini meliputi pengujian kimia, biokimia, toksikologi, dan analisis media terhadap zat warna tersebut (Pertiwi, 2013).

Akan tetapi dalam masyarakat seringkali terjadi penyalahgunaan zat pewarna untuk sembarang bahan pangan, misalnya zat pewarna untuk tekstil dan kulit dipakai untuk mewarnai bahan pangan. Hal ini jelas sangat berbahaya bagi kesehatan karena adanya residu logam berat pada zat pewarna tekstil. Timbulnya penyalahgunaan tersebut antara lain disebabkan oleh ketidaktahuan masyarakat mengenai zat pewarna untuk pangan, dan disamping itu harga zat pewarna untuk industri jauh lebih murah dibandingkan dengan harga zat pewarna untuk pangan. Oleh karena itu, pada penelitian ini, beberapa sampel saus

\section{MATERIAL DAN METODE}

\section{Bahan dan Alat}

Bahan-bahan yang digunakan dalam penelitian ini adalah produk saus yang dipasarkan di Kota Banda Aceh. Sedangkan, bahan-bahan kimia untuk analisis adalah Rhodamin B, benang wol, aquadest, etanol 96\%, eter, larutan $\mathrm{NaOH} 1 \%$, larutan $\mathrm{NaOH} 10 \%$, larutan amonia $2 \%$ (yang dilarutkan dalam etanol $70 \%$ ) asam asetat $10 \%$, dan larutan amonia $10 \%$ (yang dilarutkan dalam etanol 70\%), kertas saring Whatman No. 42, isopropanol, amonia,aluminium foil, plastic wrapping, kertas lakmus, $\mathrm{HCl} \mathrm{10 \% ,} \mathrm{NaOH} 10 \%, \mathrm{HCl}$ pekat, $\mathrm{H}_{2} \mathrm{SO}_{4}$ pekat, $\mathrm{NH}_{4} \mathrm{OH} 12 \%$. Alat-alat yang digunakan dalam penelitian ini adalah Chamber elusi, timbangan analitik, gelas ukur, gelas kimia, corong pemisah, labu takar, pipet tetes, pipet volum, bulb, spatula, batang pengaduk, plat tetes, Spektrofotometer UV- vis, pemanas air, gunting.

\section{Metode}

Pengambilan sampel dilakukan berdasarkan tempat penjualan produk saus yaitu 3 sampel saus cabe dari pasar tradisional Peunayong dan 3 sampel saus tomat dari Suzuya Mall. Pengambilan sampel saus cabe dari pasar tradisional Peunayong dilakukan untuk saus cabe merk Tradisional, Dena dan Bandar dimana sampel saus cabe ini tidak dipasarkan di Suzuya Mall, Setui. Sedangkan pengambilan sampel di Suzuya Mall, Setui dilakukan dengan melakukan survei terhadap konsumen yang berbelanja di Suzuya Mall Setui terlebih dahulu. Survei dilakukan dengan teknik incidental sampling yaitu pemilihan konsumen berdasarkan kebetulan, yaitu siapa saja yang membeli produk saus dapat dijadikan sebagai responden. Responden yang dipilih merupakan orang-orang dewasa yang sedang berbelanja. Dari hasil survei, tujuh produk saus (merk ABC, Sasa, Weiwang, Dua Belibis, Umami, Indofood dan

Analisa pewarna sintetis non pangan Rhodamin B dan Methanyl Yellow pada produk saus yang dipasarkan di Kota Banda Aceh (Ulul Azmi, Ismail Sulaiman, Melly Novita)

Jurnal Ilmiah Mahasiswa Pertanian Unsyiah, Vol. 2, No. 3, Agustus 2017: 210-215 
Del Monte) diketahui. Selanjutnya tiga produk saus tomat (Sasa, Indofood, dan ABC) dengan jumlah pembelian terbanyak dipilih sebagai sampel saus dari Suzuya Mall Setui. Dengan demikian, total sampel saus yang dianalisis pewarnaannya dalam penelitian ini berjumlah enam sampel. Untuk selanjutnya sampel saus tersebut akan disebut dengan sampel 1 untuk saus merk Tradisional, sampel 2 untuk saus merk Dena, sampel 3 untuk saus merk Bandar, sampel 4 untuk saus merk Sasa, sampel 5 untuk saus merk Indofood, sampel 6 untuk saus merk ABC. Sedangkan keempat sampel lainnya yaitu sampel 7 (Weiwang), sampel 8 (Dua Belibis), sampel 9 (Umami) dan sampel 10 (Del Monte) tidak dilanjutkan untuk analisis pewarnaan.

\section{Analisis Data}

Hasil pengamatan mengenai kandungan zat pewarna sintetik Rhodamin B atau Methanyl Yellow pada setiap sampel dianalisis secara kualitatif dan disajikan secara deskriptif. Metode deskriptif yaitu untuk membuat deskipsi, gambaran atau lukisan secara sistematis, faktual dan akurat mengenai fakta-fakta, sifat-sifat serta hubungan antar fenomena yang diselidiki.

\section{HASIL DAN PEMBAHASAN}

\section{Hasil Survei}

Dalam melakukan pengambilan sampel saus tomat yang dipasarkan dari pasar moderen Suzuya Mall Setui, peneliti terlebih dahulu melakukan survei kepada pembeli, terhadap jumlah daya beli produk saus dan 3 produk saus tomat dengan pembelian terbanyak menjadi pilihan sampel. Survei di Suzuya Mall Setui dilakukan dengan teknik incidental sampling yaitu pemilihan responden yang berdasarkan kebetulan, siapa saja yang ditemui oleh peneliti dan memenuhi kriteria yang telah ditetapkan yaitu responden yang ditemui sedang membeli saus tomat dan bersedia untuk diwawancarai. Adapun responden yang diperoleh dari hasil survei yang telah dilakukan di Suzuya Mall Setui berjumlah 145 orang. Hasil survei pemilihan sampel saus dari Suzuya Mall Setui dapat dilihat pada Tabel 1. Ketiga sampel saus tomat terbanyak yang dipilih oleh konsumen yaitu sampel 6, sampel 5 dan sampel 4 . Selanjutnya ketiga sampel tersebut dianalisis secara kualitatif dengan metode kromatografi kertas 1 dimensi.

Tabel 1. Hasil Survei Jumlah Konsumen Saus Tomat di Suzuya Mall Setui.

\begin{tabular}{ccccc}
\hline No. & Merk Saus Tomat & Minggu 1 & Minggu 2 & Jumlah \\
\hline 1. & Sampel 6 & 32 & 57 & 89 \\
2. & Sampel 5 & 17 & 26 & 43 \\
3. & Sampel 4 & 4 & 7 & 11 \\
4. & Sampel 7 & 2 & 0 & 2 \\
5. & Sampel 9 & 0 & 0 & 0 \\
6. & Sampel 8 & 0 & 0 & 0 \\
7. & Sampel 10 & 0 & 0 & 0 \\
\hline
\end{tabular}

\section{Hasil Analisis Pewarnaan}

Sampel yang diuji dalam penelitian ini berjumlah 6 sampel, yaitu 3 sampel saus tomat dari pasar modern dan 3 sampel saus cabe dari pasar tradisional yang dipasarkan di Kota Banda Aceh. Hasil uji ini dilakukan secara kualitatif dengan metode kromatografi kertas 1 dimensi.

Analisa pewarna sintetis non pangan Rhodamin B dan Methanyl Yellow pada produk saus yang dipasarkan di Kota Banda Aceh (Ulul Azmi, Ismail Sulaiman, Melly Novita)

Jurnal Ilmiah Mahasiswa Pertanian Unsyiah, Vol. 2, No. 3, Agustus 2017: 210-215 
Berdasarkan hasil penelitian yang telah dilakukan di Laboratorium Balai Pengawasan Obat dan makanan (BPOM) tentang analisis zat pewarna Rhodamin B dan Methanyl Yellow pada saus di Kota Banda Aceh maka diperoleh hasil penelitian sebagai berikut:

Tabel 2. Uji Kualitatif zat pewarna Rhodamin B pada saus tomat dan saus cabe di Kota Banda Aceh.

\begin{tabular}{ccccc}
\hline \multirow{2}{*}{ No } & Sampel saus & \multicolumn{3}{c}{ Hasil uji pemeriksaan Organoleptik dan Kimia } \\
\cline { 3 - 5 } & & Warna & $\begin{array}{c}\text { Identifikasi } \\
\text { Rhodamin B }\end{array}$ & Metode/Pustaka \\
\hline 1 & Sampel 1 & Merah & Tidak terdeteksi & KK/SNI 01 2895 1992 \\
2 & Sampel 2 & Merah & Tidak terdeteksi & KK/SNI 01-2895-1992 \\
3 & Sampel 3 & Merah & Tidak terdeteksi & KK/SNI 01-2895-1992 \\
4 & Sampel 4 & Merah & Tidak terdeteksi & KK/SNI 01-2895-1992 \\
5 & Sampel 5 & Merah & Tidak terdeteksi & KK/SNI 01-2895-1992 \\
6 & Sampel 6 & Merah & Tidak terdeteksi & KK/SNI01 2895-1992 \\
\hline
\end{tabular}

Tabel 3. Uji Kualitatif zat pewarna Methanyl Yellow pada saus tomat dan saus cabe di Kota Banda Aceh.

\begin{tabular}{ccccc}
\hline \multirow{2}{*}{ No } & Sampel saus & \multicolumn{3}{c}{ Hasil uji pemeriksaan Organoleptik dan Kimia } \\
\cline { 3 - 5 } & & Warna & $\begin{array}{c}\text { Identifikasi } \\
\text { Merhanyl Yellow }\end{array}$ & Metode/Pustaka \\
\hline 1 & Sampel 1 & Merah & Tidak terdeteksi & KK/SNI 01 2895 1992 \\
2 & Sampel 2 & Merah & Tidak terdeteksi & KK/SNI 01-2895-1992 \\
3 & Sampel 3 & Merah & Tidak terdeteksi & KK/SNI 01-2895-1992 \\
4 & Sampel 4 & Merah & Tidak terdeteksi & KK/SNI 01-2895-1992 \\
5 & Sampel 5 & Merah & Tidak terdeteksi & KK/SNI 01-2895-1992 \\
6 & Sampel 6 & Merah & Tidak terdeteksi & KK/SNI01 2895-1992 \\
\hline
\end{tabular}

\section{Pembahasan}

Dari tabel uji kualitatif zat pewarna Rhodamin $B$ yang telah dilakukan pada 6 sampel saus yang dipasarkan di Kota Banda Aceh dinyatakan bahwa dari uji organoleptik warna diperoleh hasil normal sesuai dengan SNI 01-3546-2004. Hasil uji kimia yang dilakukan pada sampel saus menunjukkan bahwa tidak terdeteksi adanya kandungan zat pewarna Rhodamin $B$ pada seluruh sampel saus tomat dan saus cabe yang dianalisis (Tabel 2). Sedangkan jika saus yang mengandung Rhodamin $B$ dapat diketahui dengan cara melihat perubahan warna sampel saus dibawah sinar UV $254 \mathrm{~nm}$ dan $366 \mathrm{~nm}$, warna saus akan berfluoresensi menjadi kuning/jingga serta nilai $\mathrm{Rf}$ yang sama atau hampir sama dengan $\mathrm{Rf}$ standar baku Rhodamin B. Pada uji kualitatif zat pewarna Methanyl Yellow juga tidak terdeteksi adanya kandungan zat pewarna Methanyl Yellow pada keenam sampel saus tomat dan saus cabe yang dianalisis (Tabel 3). Saus yang mengandung Methanyl Yellow akan terjadi perubahan warna ungumerah pada $\mathrm{HCl}$ pekat, ungu pada $\mathrm{H}_{2} \mathrm{SO}_{4}$ pekat, tidak berubah warna $\mathrm{NaOH} 10 \%$ dan tidak berubah warna pada $\mathrm{NH}_{4} \mathrm{OH} 12 \%$ menunjukkan adanya pewarna Methanyl Yellow pada sampel.

Analisa pewarna sintetis non pangan Rhodamin B dan Methanyl Yellow pada produk saus yang dipasarkan di Kota Banda Aceh (Ulul Azmi, Ismail Sulaiman, Melly Novita)

Jurnal Ilmiah Mahasiswa Pertanian Unsyiah, Vol. 2, No. 3, Agustus 2017: 210-215 
Deteksi noda pada KLT dapat dilakukan secara kimia dan fisika. Cara kimia yang biasa digunakan adalah dengan mereaksikan bercak dengan suatu pereaksi melalui penyemprotan sehingga bercak menjadi jelas. Cara fisika yang dapat digunakan untuk menampakkan noda adalah dengan pencacahan radioaktif dan fluorosensi sinar ultraviolet. Fluorosensi sinar ultraviolet terutama untuk senyawa yang dapat berfluorosensi, membuat bercak terlihat jelas (Gandjar, 2007).

Dari hasil penelitian ini menunjukkan bahwa keenam sampel saus yang beredar di Banda Aceh tersebut aman dari penggunaan zat pewarna sintetik Rhodamin B dan Methanyl Yellow. Seperti yang diketahui, hampir seluruh kalangan masyarakat mengkonsumsi saus sebagai pelengkap citarasa makanan seperti bakso, gorengan, mie, kerupuk dan lain-lain. Selain remaja dan orang dewasa, anak-anak bahkan balita juga gemar mengkonsumsi saus. Oleh karena itu sangat berbahaya apabila saus yang dikonsumsi mengandung pewarna sintetik seperti Rhodamin B dan Methanyl Yellow. Konsumsi Rhodamin B dan Methanyl Yellow melebihi jumlah tertentu dapat menyebabkan penyakit-penyakit berbahaya seperti kanker dan kerusakan ginjal. Menurut Sumarlin (2010) dari hasil analisis berupa penelitian menyatakan bahwa Rhodamin $B$ dapat membahayakan kesehatan manusia yaitu tidak dapat dicerna oleh tubuh dan dapat mengendap secara utuh dalam hati sehingga dapat menyebabkan keracunan hati. Pengaruh toksisitas biasanya bersifat akut saja yaitu yang pengaruhnya cepat terjadi, sedangkan pengaruh yang bersifat kronis tidak dapat diketahui secara cepat karena manusia yang normal memiliki toleransi yang tinggi terhadap racun dalam tubuh dengan adanya mekanisme detoksifikasi. Selain itu pembeli juga diduga mengonsumsi menu yang berbeda setiap harinya.

Produk pangan ilegal adalah produk pangan tidak terdaftar dan tidak memiliki izin edar, Artinya produk tersebut tidak melalui proses evaluasi keamanan, mutu dan gizi dari instansi yang berwenang, misalnya Badan POM dan Dinas Kesehatan. BPOM berwenang mengeluarkan nomor ijin edar dengan kode MD untuk pangan olahan dalam kemasan produksi dalam negeri atau kode ML untuk pangan olahan dalam kemasan produksi luar negeri, kemudian kode tersebut diikuti beberapa digit nomor/angka, yang setiap digitnya memiliki arti tertentu, apabila produsen/industri pangan olahan mengajukan pendaftaran dan telah memenuhi persyaratan keamanan pangan yang ditetapkan (Banun, 2015). Dari keenam sampel produk saus tomat dan saus cabe, sampel 4, 5 dan 6 memiliki izin edar MD sedangkan sampel 1, 2 dan 3 hanya memiliki izin edar dari Dinas kesehatan.

Dari keenam sampel saus yang dianalisis terdapat perbedaan warna dimasing masing sampel saus. Ada yang bewarna merah gelap dan ada juga yang berwarna merah terang. Perbedaan warna pada sampel saus tomat tidak bisa digunakan sebagai patokan bahwa saus tersebut mengandung pewarna non pangan. Perbedaan warna pada masing-masing sampel saus bisa disebabkan oleh pemilihan bahan baku yang berbeda sehingga mempengaruhi mutu dari saus tersebut. Menurut Suprapti (2000) saus tomat memiliki warna merah tua, padahal sebelumnya warna tomat yang asli adalah merah cerah. Hal ini dikarenakan sebelum proses pengolahan dipilih buah tomat yang tidak memiliki bagian yang berwarna hijau atau hitam, yang nantinya akan mempengaruhi warna saus tomat menjadi kecoklatan sehingga menurunkan mutu dari saus tomat.

Dari hasil survei yang telah dilakukan terhadap produk yang dipasarkan, masing-masing konsumen memiliki pendapat yang berbeda-beda dalam memilih produk saus yang ingin dibeli. Menurut Rosipah (2013) terkadang preferensi konsumen dapat dipengaruhi oleh karakteristik individu (jenis kelamin, umur, pendidikan, pendapatan dan pengaetahuan gizi), karakteristik makanan (rasa, rupa, bentuk dan tekstur) serta karakteristik lingkungan (pekerjaan, jumlah keluarga, mobilitas dan musim).

Analisa pewarna sintetis non pangan Rhodamin B dan Methanyl Yellow pada produk saus yang dipasarkan di Kota Banda Aceh (Ulul Azmi, Ismail Sulaiman, Melly Novita)

Jurnal Ilmiah Mahasiswa Pertanian Unsyiah, Vol. 2, No. 3, Agustus 2017: 210-215 
Hipotesis adalah suatu jawaban yang bersifat sementara terhadap suatu Penelitian, sampai terbukti melalui data yang terkumpul (Arikunto, 2006). Berdasarkan uraian dari Tabel 2 dan 3 yang telah dijelaskan di atas, hipotesis penelitian yang menyebutkan bahwa saus yang dipasarkan di Kota Banda Aceh mengandung bahan tambahan pewarna Rhodamin $B$ dan Methanyl Yellow ditolak. Hasil analisis menunjukkan tidak terdeteksi adanya kandungan zat pewarna Rhodamin B dan Methanyl Yellow pada keenam sampel saus yang dianalisis.

\section{KESIMPULAN DAN SARAN}

Dari hasil analisis menunjukkan bahwa saus tomat dan saus cabe yang dipasarkan di Kota Banda Aceh tidak mengandung bahan pewarna Rhodamin B dan Methanyl Yellow. Warna saus tomat dan saus cabe yang dipasarkan di Kota Banda Aceh adalah normal sesuai dengan SNI.

Perlu dilakukan penelitian lebih lanjut terhadap bahan pewarna non pangan lain yang biasa ditambahkan ke dalam saus tomat seperti Auramin, Butter Yellow, Magenta, Oil Yellow $A B$ dan Chrysoidin.

\section{DAFTAR PUSTAKA}

Anzar, 2016. Analisis Kandungan Zat Pewarna Sintetis Rhodamin B pada Sambal Botol yang diperdagangkan di pasar Modern Kota Kendari. Ilmu Pangan dan Teknologi Pangan Fakultas Teknologi dan Industri Pertanian, Universitas Halu Oleo, Kendari.

Banun, S., 2015. Perlindungan Hukum Terhadap Konsumen Produk Saus Sambal Indosari. Konsentrasi Hukum Bisnis Fakultas Syariah dan Hukum, Universitas Islam Negri Syarif Hidayatullah, Jakarta.

Budianto, P. E., 2008. Analisis Rhodamin B dalam Saus dan Cabe Giling di Pasar Kecamatan Laweyan Kotamadya Surakarta Dengan Metode Kromatografi Lapis Tipis. Fakultas Farmasi Universitas Muhammadiyah Surakarta, Surakarta.

Koswara, Sutrisna. 2009. Pengolahan Aneka Saus. E-book pangan, Jakarta.

Novita, M., Satriana dan E. Hasmarita. 2015. Kandungan Likopen dan Karotenoid Buah Tomat (Lycopersicum pyriforme) pada Berbagai Tingkat Kematangan: Pengaruh Pelapisan dengan Kitosan dan Penyimpanan. Jurnal Teknologi dan Industri Pertanian Indonesia Vol. 7 (1): 35-39.

Pertiwi, D., 2013. Analisis Kandungan Zat Pewarna Sintetik Rhodamin B dan Methanyl Yellow Pada Jajanan Anak di SDN Kompleks Mangkura Kota Makasar. Fakultas Kesehatan Masyarakat Universitas Hasanuddin Makasar, Makasar.

Pindyck, R.S. dan Rubinfeld, D.L., 2012. Mikroekonomi. Erlangga, Jakarta.

Rosipah, S., Burhan dan Umi P. 2013. Preferensi Konsumen terhadap Pancake dari Tepung Sukun. Jurnal Agrointek Vol. 7 (1): 53-58.

Sumarlin. L. 2010. Identifikasi Pewarna Sintesis pada Produk Pangan yang Beredar di Jakarta dan Ciputat. Jurnal Kimia Valensi Vol. 1 (6): 274-283.

Analisa pewarna sintetis non pangan Rhodamin B dan Methanyl Yellow pada produk saus yang dipasarkan di Kota Banda Aceh (Ulul Azmi, Ismail Sulaiman, Melly Novita)

Jurnal Ilmiah Mahasiswa Pertanian Unsyiah, Vol. 2, No. 3, Agustus 2017: 210-215 